\title{
Inserção da literatura local nas aulas de Língua Portuguesa: uma experiência com a literatura de Juazeiro-BA
}

\author{
Insertion of local literature in Portuguese language classes: an experience with the \\ Juazeiro-BA literature \\ Wiliana Coelho de Souza* \\ Universidade Estadual de Feira de Santana, Feira de Santana, Bahia, Brasil \\ Patrício Nunes Barreiros** \\ Universidade Estadual de Feira de Santana, Feira de Santana, Bahia, Brasil
}

\begin{abstract}
Resumo: Nesse artigo apresentamos os resultados de uma intervenção pedagógica para o ensino de Língua Portuguesa, elaborada com o objetivo de buscar alternativas para a inserção da literatura produzida por escritores juazeirenses, nas atividades de leitura e escrita de uma turma do $9^{\circ}$ ano do Ensino Fundamental do Colégio Estadual Helena Celestino Gomes, em Juazeiro-BA. Como resultado da intervenção, os alunos produziram uma biblioteca digital, na qual foi disponibilizada uma lista de escritores de Juazeiro, suas biografias e uma seleção de textos feita pelos estudantes. Para a realização das atividades que resultaram na produção da referida biblioteca, os alunos pesquisaram na Biblioteca Pública Municipal, em acervos particulares e fizeram entrevistas com escritores. As atividades foram realizadas em grupos, valorizando sempre a colaboração e a participação de todos os estudantes.
\end{abstract}

Palavras chave: Ensino de Língua Portuguesa. Escritores locais. Biblioteca Digital.

\begin{abstract}
In this article, we present the results of a pedagogical intervention for the teaching of Portuguese Language, elaborated with the objective of searching for alternatives for the insertion of the literature produced by writers from Juazeiro-BA, in the literacy activities of a 9th grade class at Elementary School Helena Celestino Gomes located in Juazeiro, Bahia. As a result of the intervention students produced a digital library in which a list of writers from Juazeiro, their biographies and a selection of texts made by the students were made available. In order to carry out the activities that resulted in the production of this library, the students carried out researches at the Municipal Public Library and in personal collections. They also interviewed writers. The activities were performed in groups, valuing students' collaboration and participation.
\end{abstract}

Keywords: Portuguese Language Teaching. Local Writers. Digital Library.

\section{PALAVRAS INICIAIS}

Nesse estudo, apresentamos alguns resultados de uma intervenção pedagógica realizada numa turma do $9^{\circ}$ ano do Ensino Fundamental, do Colégio Estadual Helena Celestino Gomes da cidade de Juazeiro-BA. A intervenção foi

\footnotetext{
* Aluna do Mestrado Profissional em Letras (ProfLetras/UEFS), professora da rede estadual de educação do Estado da Bahia. Email: wilianacsouza@gmail.com.

** Doutor em Letras e Linguística, professor Adjunto da Universidade Estadual de Feira de Santana. Email: patricio@uefs.br.
} 
planejada em formato de Sequência Didática e teve como objetivo principal ampliar as competências linguísticas dos alunos para a escrita do gênero discursivo biografia e trazer para as aulas de Língua Portuguesa a produção literária dos escritores de Juazeiro. Os alunos foram estimulados a realizar pesquisas em bibliotecas e acervos particulares, entrevistaram pessoas e, como resultado, planejaram e elaboraram uma biblioteca digital para disponibilizar as biografias produzidas e os textos dos escritores.

A principal fonte de pesquisa para a localização de documentos referentes aos escritores de Juazeiro foi o Acervo Maria Franca Pires, localizado no Departamento de Ciências Humanas (DCH III) da Universidade do Estado da Bahia - UNEB, Campus Juazeiro, que se constitui de fotografias, coleções de jornais, cadernos com entrevistas e anotações e outros materiais diversos que recontam a história cultural de Juazeiro.

É importante ressaltar que, com a proposta de valorização da literatura local e sua inserção no contexto escolar, não queremos, em hipótese alguma, diminuir o valor dos clássicos da literatura nacional. Estes já têm espaço nos livros didáticos e estão presentes nas aulas de Língua Portuguesa. O nosso interesse reside em promover o encontro do estudante com os escritores de sua cidade.

Sabe-se que a literatura, assim como outras manifestações artísticas, pode proporcionar um vínculo significativo com a realidade. Por essa razão, a literatura contribui para a formação dos indivíduos:

[...] a obra literária é uma manifestação de arte que atua sobre o indivíduo; compreendemos que a literatura possibilita o contato dele com o universo que o cerca e que sua força reside na capacidade de formação do homem (FERNANDES, 2009, p. 19).

Estando intrinsecamente ligada à formação crítica do ser humano, a literatura destaca-se por evidenciar uma gama de experiências humanizadoras que podem atuar diretamente no desenvolvimento cognitivo dos indivíduos que com ela mantém contato. Segundo Fernandes (2009), os textos literários permitem que as gerações se encontrem, pois a partir do texto literário, a geração contemporânea tem a oportunidade de conhecer as anteriores, com suas diversidades sociais e culturais.

Isso ocorre porque o texto literário carrega em si marcas do contexto em que é produzido, permitindo que o leitor possa percebê-las e o identificar. Ao perceber que aspectos culturais de seu entorno estão representados nos textos literários, os sujeitos identificam-se com a literatura a ponto de se sentirem representados culturalmente, estabelecendo uma empatia e interesse pelo texto literário. Portanto, a literatura produz significados que se transmutam na própria produção da identidade cultural, uma vez que essa identidade só pode ser pensada como situada num tempo e num espaço concretos (FREIRE, 2010). De acordo com Cosson (2014, p. 17):

$\mathrm{Na}$ leitura e na escritura do texto literário encontramos o senso de nós mesmos e da comunidade a que pertencemos. A literatura nos diz o que somos e nos incentiva a desejar e a expressar o mundo por nós mesmos. E isso se dá porque a literatura é 
uma experiência a ser realizada. É mais que um conhecimento a ser reelaborado, ela é a incorporação do outro em mim sem renúncia da minha própria identidade (COSSON, 2014, p. 17).

A projeção da identidade dos leitores num texto literário pode se tornar mais evidente quando estes são produzidos por escritores que compartilham os mesmos espaços, crenças e valores dos seus leitores. Sabemos que os escritores locais nem sempre são valorizados, especialmente pela escola. A literatura produzida por esses escritores geralmente não aparece nos livros didáticos e nem sempre está acessível para as pessoas da comunidade. Esse fato foi constatado pela nossa pesquisa, pois, apesar de existir um bom número de escritores na cidade de Juazeiro-BA, os estudantes e professores não os conhecem.

\section{A LITERATURA LOCAL E O ENSINO DE LÍNGUA PORTUGUESA}

Partimos do pressuposto de que a literatura local ainda não possui o espaço que se almeja nas salas de aula de Língua Portuguesa, embora o Artigo 26 da Lei de Diretrizes e Bases da Educação Nacional (LDB) exija que o currículo escolar do ensino básico brasileiro leve em consideração as características regionais e locais da sociedade e da cultura dos educandos.

Alguns Estados brasileiros já conseguiram avançar nesse sentido, criando leis específicas para regulamentar a inserção da literatura local nas escolas, como por exemplo:

- Tocantins - tem o Projeto de Lei No 249/2014, que inclui na Grade Curricular das Escolas Públicas Estaduais do Estado do Tocantins a Disciplina Conbecimento e Estudo dos Autores Tocantinenses;

- Piauí - teve aprovada pela Assembleia Legislativa a Lei 6.563, que dispõe sobre a adoção de livros paradidáticos de autores piauienses pelas escolas públicas e privadas do Piauí, no dia 31 de julho de 2014;

- Mato Grosso - dispõe de uma lei que trata sobre a obrigatoriedade do ensino das disciplinas de História, Geografia e Literatura de Mato Grosso, nas Escolas de $1^{\circ}$ e $2^{\circ}$ Graus, públicas ou particulares, que funcionem no Estado, a Lei No 5.573, de 06 de fevereiro de 1990 - D.O. 17.04.90;

- Ceará - possui o Projeto de Lei N. $78 / 14$ em trâmite, que inclui a disciplina Conbecimento e Estudo dos Autores Cearenses na grade curricular das escolas públicas mantidas pelo Governo do Estado do Ceará.

Além da criação de leis, é fundamental que se ofereçam subsídios para que os professores tenham condições de adequar suas práticas pedagógicas, pois não adianta haver elaboração de leis sem que haja material disponível para que esse ensino tenha uma aplicabilidade eficaz.

No caso da literatura local, é preciso considerar a questão do acesso aos textos. De nada adiantará sugerir a inserção dessa literatura no contexto escolar, se não houver disponibilidade dos textos. Para que a literatura local esteja presente nas aulas de Língua Portuguesa, é necessário dispor de um acervo na escola para consulta ou que as obras locais estejam nas bibliotecas; no entanto, as obras dos 
escritores locais dificilmente estão presentes nesses espaços. Uma alternativa seria explorar os acervos particulares, tanto de escritores, quanto de pessoas da comunidade que se preocuparam em arquivar a memória literária local. Nos acervos particulares é possível encontrar livros, textos inéditos, cadernos, panfletos, recortes de jornais e outros tipos de documentos que são suportes dos textos literários. A escola pode ser uma agente de valorização desses acervos, explorando a sua documentação e favorecendo o seu encontro com os leitores. No contexto das tecnologias digitais, isso pode ser facilitado por meio da digitalização, permitindo a circulação dos textos na Web.

É importante frisar que inserir a literatura local nas aulas de Língua Portuguesa também é oportunizar aos alunos o conhecimento acerca de sua própria história. Nessa perspectiva, o texto literário pode motivar debates na sala de aula, mediados por uma ação colaborativa e participativa. Isso pode contribuir para o melhor desenvolvimento de uma consciência cidadã e protagonista, principalmente se essa construção coletiva resultar num trabalho relacionado à tecnologia digital que dispõe de ferramentas acessíveis aos jovens e que estes manipulam com certa facilidade.

Segundo os Parâmetros Curriculares Nacionais (PCN) o ensino de Língua Portuguesa no Ensino Fundamental deve possibilitar, entre outras coisas, que os alunos possam:

- Utilizar a linguagem na escuta e produção de textos orais e na leitura e produção de textos escritos de modo a atender a múltiplas demandas sociais, responder a diferentes propósitos comunicativos e expressivos, e considerar as diferentes condições de produção do discurso;

- Utilizar a linguagem para estruturar a experiência e explicar a realidade, operando sobre as representações construídas em várias áreas do conhecimento:

- sabendo como proceder para ter acesso, compreender e fazer uso de informações contidas nos textos, reconstruindo o modo pelo qual se organizam em sistemas coerentes;

- sendo capaz de operar sobre o conteúdo representacional dos textos, identificando aspectos relevantes, organizando notas, elaborando roteiros, resumos, índices, esquemas etc.;

- aumentando e aprofundando seus esquemas cognitivos pela ampliação do léxico e de suas respectivas redes semânticas;

- Analisar criticamente os diferentes discursos, inclusive o próprio, desenvolvendo a capacidade de avaliação dos textos:

- contrapondo sua interpretação da realidade a diferentes opiniões;

- inferindo as possíveis intenções do autor marcadas no texto;

- identificando referências intertextuais presentes no texto;

- percebendo os processos de convencimento utilizados para atuar sobre o interlocutor/leitor;

- identificando e repensando juízos de valor tanto socioideológicos (preconceituosos ou não) quanto históricoculturais (inclusive estéticos) associados à linguagem e à língua;

- reafirmando sua identidade pessoal e social; (BRASIL, 1998, p. 89).

Esses objetivos evidenciam que a identidade pessoal e social de um grupo precisa ser reafirmada a partir de situações em que ela seja posta em discussão, seja por meio de leituras ou produções diversas. 
Os PCN tratam, ainda, da relação entre as Tecnologias da Informação e o ensino de Língua Portuguesa, corroborando com a ideia de que o uso das tecnologias não deve limitar-se ao mero instrumento da prática pedagógica, mas abranger as práticas sociais nas quais elas estão inseridas para:

Conhecer a linguagem videotecnológica própria desse meio; analisar criticamente os conteúdos das mensagens, identificando valores e conotações que veiculam; fortalecer a capacidade crítica dos receptores, avaliando as mensagens; produzir mensagens próprias, interagindo com os meios (BRASIL, 1998, p. 89).

Portanto, consideramos viável e atrativa a proposta de construção de uma biblioteca digital organizada pelos estudantes, considerando o atual acesso e envolvimento dos jovens com o universo tecnológico e também pela facilidade de disseminação de informações, tendo em vista que, muitas vezes, bibliotecas físicas são escassas ou não suprem a necessidade dos interessados.

Ao traçar um panorama acerca da presença de bibliotecas em Juazeiro-BA, notamos que as escolas públicas locais nem sempre dispõem desse dispositivo de incentivo à leitura. A cidade conta apenas com a Biblioteca Pública Municipal Professor Aristóteles Pires de Carvalho. Realizamos uma pesquisa nessa biblioteca, no acervo Maria Franca Pires e em páginas da internet para elaborar uma lista prévia de escritores de Juazeiro. Identificamos 57 escritores (Cf. Quadro 1), mas somente 27 deles têm algum livro disponível na Biblioteca Municipal. Quanto aos demais, podemos encontrar seus textos em jornais antigos do acervo Maria Franca Pires ou em sites.

Quadro 1 - Escritores de Juazeiro-BA

\begin{tabular}{|c|c|}
\hline ESCRITORES & $\begin{array}{c}\text { POSSUEM OBRAS } \\
\text { DISPONÍVIES NA BPM }\end{array}$ \\
\hline 1. Agostinho José Muniz & \\
\hline 2. Antonila da França Cardoso & $\mathbf{X}$ \\
\hline 3. Antonio Carlos Coelho de Assis (Coelhão) & \\
\hline 4. Antônio Djalma Palma & \\
\hline 5. Armando Almeida Filho & \\
\hline 6. Carlos Alberto da Silva Martins & $\mathbf{X}$ \\
\hline 7. Carlos Augusto Cruz & $\mathbf{X}$ \\
\hline 8. Carlos Mauricio Dias Cordeiro & \\
\hline 9. Creuza Maria Gonçalves Mascarenhas & $\mathbf{X}$ \\
\hline 10. Demar Guerra & \\
\hline 11. Dilton Libório & \\
\hline 12. Ednei Ribeiro & $\mathbf{X}$ \\
\hline 13. Elmo Aureliano & $\mathbf{X}$ \\
\hline 14. Ermi Ferrari Magalhães & $\mathbf{X}$ \\
\hline 15. Euvaldo Macedo & $\mathbf{X}$ \\
\hline 16. Expedito Almeida & $\mathbf{X}$ \\
\hline 17. Galvão dos Novos Bahianos & $\mathbf{X}$ \\
\hline 18. Geraldo Dias de Andrade & $\mathbf{X}$ \\
\hline 19. Gildete Lino de Carvalho & \\
\hline 20. Giuseppe Muccini & \\
\hline 21. Heráclio França & $\mathbf{X}$ \\
\hline 22. James José de Carvalho Cadidé & \\
\hline 23. João Clemente Meireles Santana & \\
\hline 24. Jorge Dantas & \\
\hline
\end{tabular}


ISSN $1415-8973$

\begin{tabular}{|c|c|}
\hline 25. Jorge de Souza Duarte & $\mathbf{X}$ \\
\hline 26. José Araújo Lopes & $\mathbf{X}$ \\
\hline 27. José Eurico Pereira de Oliveira & \\
\hline 28. José Mauricio Farias Nascimento & \\
\hline 29. José Vitor dos Santos & $\mathbf{X}$ \\
\hline 30. Joseph Bandeira & $\mathbf{X}$ \\
\hline 31. Josias & \\
\hline 32. Jurandir Oliveira Costa & $\mathbf{X}$ \\
\hline 33. Layse de Luna Britto & \\
\hline 34. Lucio Emanuel & $\mathbf{X}$ \\
\hline 35. Luiz Antônio Duarte & $\mathbf{X}$ \\
\hline 36. Manuca Almeida & $\mathbf{X}$ \\
\hline 37. Márcio Fabiano e Rogério Leal & $\mathbf{X}$ \\
\hline 38. Maria do Carmo Sá Nogueira & \\
\hline 39. Mauriçola & \\
\hline 40. Paulo Marques Benevides & \\
\hline 41. Pedro Raymundo & $\mathbf{X}$ \\
\hline 42. Pereira de Oliveira & $\mathbf{X}$ \\
\hline 43. Raul da Rocha de Queiroz & \\
\hline 44. Rosalina Rodrigues & $\mathbf{X}$ \\
\hline 45. Sebastião Simão Filho & $\mathbf{X}$ \\
\hline 46. Tarciso Moraes & $\mathbf{X}$ \\
\hline 47. Walter Doutorado & $\mathbf{X}$ \\
\hline
\end{tabular}

Fonte: Elaborado pelos autores.

A Biblioteca Pública Municipal de Juazeiro (BPM) é frequentada por estudantes da educação básica para consultar enciclopédias, livros técnicos ou clássicos da literatura nacional. Segundo informações nos registros da BPM, raramente as obras dos escritores juazeirenses são consultadas.

Dos vinte e três colégios da rede pública estadual, localizados na área urbana da cidade de Juazeiro-BA, somente nove dispõem de bibliotecas, mas seus acervos não contam com obras dos escritores juazeirenses.

\section{A SEQUÊNCIA DIDÁTICA PARA ELABORAÇÃO DA BIOGRAFIA DOS ESCRITORES E A CONSTRUÇÃO DA BIBLIOTECA DIGITAL}

Os estudos acerca do ensino-aprendizagem de línguas têm destacado a relevância do trabalho com os gêneros orais e escritos na escola como um dos meios para garantir aos alunos uma experiência satisfatória com os usos sociais da língua, já que, segundo Bakhtin (1992, p. 301), os gêneros do discurso, compreendidos como enunciados relativamente estáveis, "[...] que nos são dados quase como nos é dada a língua materna, que dominamos com facilidade, antes mesmo que the estudemos a gramática [...].” Isso significa que

Aprender a falar é aprender a estruturar enunciados [...] [pois] os gêneros do discurso organizam nossa fala da mesma maneira que a organizam as formas gramaticais. [...] Se não existissem os gêneros do discursos e se não os dominássemos, se tivéssemos de construir cada um dos novos enunciados, a comunicação verbal seria quase impossível (BAKHTIN, 1992, p. 301-302). 
O Plano Nacional do Livro Didático (BRASIL, 2006) e os Parâmetros Curriculares Nacionais (BRASIL, 2007) já reivindicaram a inserção dos gêneros textuais na escola, promovendo um intenso debate acerca da mudança de paradigma no ensino de Língua Portuguesa no Brasil. Mas não basta apenas reconhecer a relevância dos gêneros textuais, é preciso criar mecanismos de didatização, ou seja, meios de inseri-los no cotidiano das aulas de Língua Portuguesa. Nesse aspecto, não existe uma receita pronta, pois o professor precisa transformar o espaço da sala de aula num laboratório, desenvolvendo novas estratégias metodológicas e mantendo-se atualizado para aproveitar as experiências exitosas, adequando-as a seu contexto. Segundo Dell’Isola (2007, p. 24):

A identidade, os relacionamentos e o conhecimento dos seres humanos são determinados pelos gêneros textuais a que estão expostos, que produzem e consomem. O estudo dos gêneros possibilita a exploração de algumas regularidades nas esferas sociais em que eles são utilizados. Por isso, qualquer profissional da área de ensino de língua deveria levar em conta esse aspecto no trabalho com o aprendiz (DELLA'ISOLA, 2007, p. 24).

Como se pode notar, os gêneros textuais manifestam-se nos usos sociais da língua e estão presentes no cotidiano. Nesse sentido, não caberia mais um modelo de ensino que se concentrasse em formas abstratas da língua. O trabalho com gêneros textuais (orais e escritos), no âmbito escolar, não se limita apenas a explorar as propriedades formais a que os textos estão submetidos, seus aspectos materiais propriamente. Os diferentes usos sociais dos gêneros, suas diferentes formas de materialização e suas capacidades comunicativas passaram a ocupar lugar de destaque no ensino da língua, somando-se aos aspectos formais de cada gênero em particular. Isso evidencia que o estudo dos usos sociais da linguagem ultrapassa os seus limites formais e amplia as capacidades de articulação dos sujeitos nas interações sociais.

É importante que os alunos percebam a multiplicidade de gêneros que os cercam e passem a analisar, compreender e produzir os textos com base nas diferentes condições de produção e situações de uso da linguagem. Ao refletir acerca da prática de linguagem no espaço escolar, Rojo (2000) aponta para o desenvolvimento de atividades com gêneros, ressaltando que a sua inserção no espaço escolar é uma oportunidade ímpar de concretizar os usos sociais da língua como ela se realiza no cotidiano.

Assim, cabe à escola mobilizar os aspectos ensináveis de determinado gênero. A esse tipo de ação pedagógica costuma-se chamar de didatização dos gêneros, que leva à elaboração de um Modelo Didático do Gênero (MDG) e está fundamentado no Interacionismo Sociodiscursivo (ISD). Esta teoria o descreve como necessário para alcançar os objetivos de ensino-aprendizagem de gêneros. O MDG possibilita a elaboração de uma sequência didática como alternativa para o desenvolvimento das capacidades de linguagem do aluno, visto que não convém utilizar uma sequência didática sem antes realizar o estudo do gênero sobre o qual se pretende trabalhar.

De acordo com Machado e Cristovão (2006), a construção de um MDG exige uma série de elementos particulares para atender às suas necessidades, como: as 
características da situação de produção desse gênero, seus conteúdos peculiares, as diversas maneiras de mobilizar esses conteúdos, a confecção composicional típica do gênero e seu estilo particular. Essa construção, segundo as autoras, permite ainda uma "visualização das dimensões constitutivas do gênero e seleção das que podem ser ensinadas e das que são necessárias para um determinado nível de ensino" (MACHADO; CRISTOVÃO, 2006, p. 557).

A sequência didática que usufrui desse MDG, é considerada, portanto, como um conjunto de sequências de atividades progressivas, planejadas, direcionadas por um tema, com vistas a uma produção final. Assim, a abordagem da perspectiva do ISD é justificada por ter seu enfoque direcionado para o ensino dos gêneros textuais a partir do desenvolvimento progressivo das capacidades de linguagem dos alunos, estruturada numa sequência didática. De acordo com Dolz, Noverraz e Schneuwly (2004, p. 98), a estrutura básica de uma sequência didática pode ser representada em quatro etapas:

Figura 01 - Esquema da Sequência Didática de Dolz, Noverraz e Schneuwly

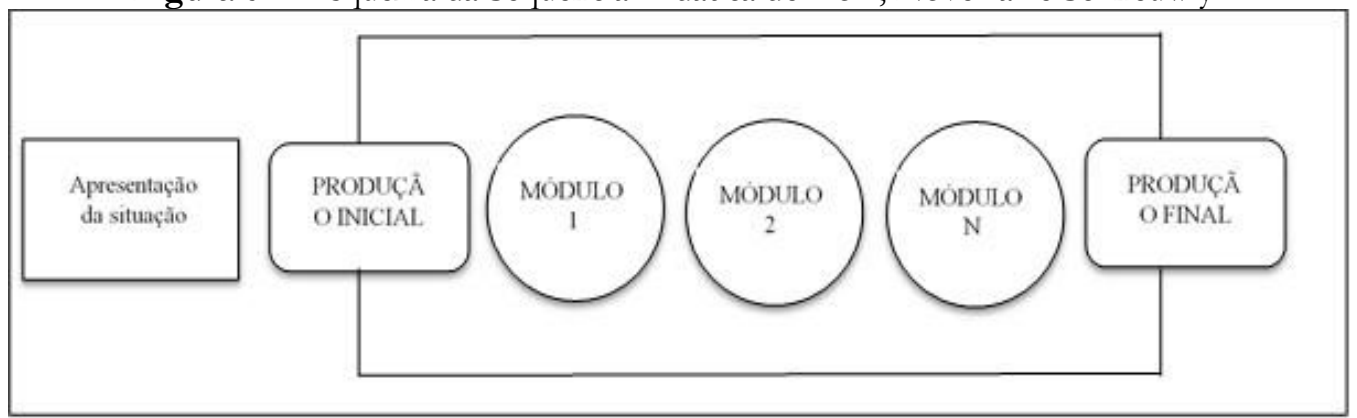

Fonte: Dolz, Noverraz e Schneuwly (2004, p. 98).

Nesse modelo, inicia-se com a apresentação de uma situação de interação sociocomunicativa real, que contextualiza os usos sociais do gênero discursivo. $\mathrm{Na}$ sequência, o aluno produz um texto, considerado como produção inicial. Essa produção inicial oferecerá ao professor subsídios para diagnosticar a compreensão que o aluno tem do referido gênero. Depois, com base na produção inicial, sistematiza-se a intervenção e a elaboração de módulos que irão direcionar a produção final. Trata-se, portanto, de ações sistemáticas de planejamento de ensinoaprendizagem que seguem uma lógica progressiva.

Costa-Hübes (2009) propõe uma adaptação do modelo apresentado por Dolz, Noverraz e Schneuwly (2004). Tal adaptação propõe um módulo de reconhecimento do gênero antes da produção inicial para que os estudantes tenham a oportunidade de conhecer várias situações que envolvam a prática de leitura de textos do gênero, já prontos, que circulam na sociedade. 
Figura 02 - Esquema da Sequência Didática apresentado por Costa-Hübes (2009)

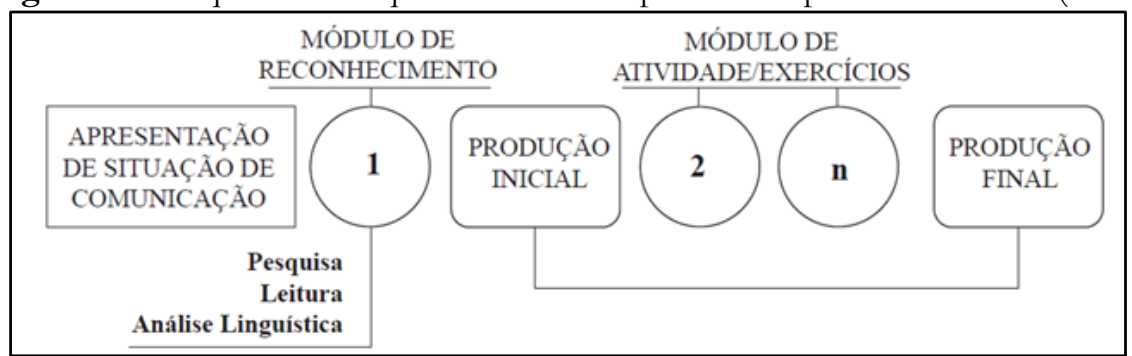

Fonte: Costa-Hübes (2009).

Realizamos algumas adaptações desses dois modelos para a estruturação de uma SD. A seguir, destacaremos algumas reflexões que suscitaram tais adaptações, levando em consideração a SD que planejamos para o presente estudo:

a) Geralmente os professores planejam as atividades de ensino-aprendizagem sem efetivamente levar em consideração o ponto de vista dos estudantes, mas eles podem ser inseridos no planejamento, opinando a respeito de como e o que pode ser feito para favorecer o aprendizado. Desse modo, os estudantes se sentirão corresponsáveis pelas ações da SD. Por isso, propomos uma etapa de Planejamento da Proposta da SD que envolveu os alunos (Cf. Figura 3, item 1). Eles sugeriram estratégias e ações que já tínhamos previsto e comentaram animadamente sobre algumas ações específicas. Para os estudantes, foi também atrativo o fato de poderem sair dos muros da escola, visitar lugares e entrevistar pessoas.

b) Antes mesmo de apresentar uma situação de comunicação na qual o gênero esteja presente, faz-se necessário realizar uma Sondagem com o objetivo de conhecer as situações de comunicação que os alunos vivenciam em seu cotidiano e como o gênero discursivo em questão faz parte da vida deles (Cf. Figura 3, item 2). Quando o professor desconhece as práticas sociais de comunicação dos alunos, pode cometer equívocos na mediação, apresentado formas de materialização do gênero que estão distantes da realidade dos estudantes. Portanto, achamos adequado realizar uma sondagem antes do módulo de apresentação do gênero. Na sondagem, investigamos acerca do uso das mídias digitais, do acesso a obras literárias e pudemos dimensionar algumas ações.

c) A partir do material coletado na sondagem foi elaborada uma Apresentação do gênero (Cf. Figura 3, item 3), com o intuito de demonstrar para os alunos as características formais do gênero biografia, ou seja, apresentamos o Modelo Didático do Gênero.

d) Após a atividade de Apresentação do gênero, entendemos que os alunos teriam condições de fazer uma Pesquisa de Campo (Cf. Figura 3, item 4), com o objetivo de coletar informações sobre os escritores juazeirenses e, se possível, exemplos de biografias dos mesmos. Os alunos apresentaram o material coletado e foi promovido um rico debate acerca das informações levantadas e dos mecanismos de preservação da memória local.

e) Com o material coletado na Pesquisa de Campo, foi elaborado o Módulo de Reconhecimento do Gênero (Cf. Figura 3, item 5). Nesse módulo, foram apresentadas formas de materialização do gênero ao qual os alunos não estavam habituados, mas partimos de conhecimentos que estivessem o mais próximo possível dos 
estudantes. Agindo dessa forma, tivemos condições de produzir um módulo adequado à realidade dos alunos, ou seja, um material personalizado e que atendeu às necessidades específicas do grupo.

e) Insistimos na produção de um texto para uso concreto, ou seja, o aluno produziu textos para encontrar, efetivamente, interlocutores na vida social, transcendendo os muros da escola. Portanto, partimos de uma Produção Inicial (Cf. Figura 3, item 6), que suscitou a elaboração de Módulos de Intervenção (Cf. Figura 3, item 7), com vista à Produção Final e à Culminância. $\mathrm{O}$ encontro do texto com os interlocutores ocorreu após o estudo progressivo do gênero e atividades de reescrita, incluindo a transposição do texto do meio analógico para o digital e as diversas implicações de lidar com a multimodalidade. A seguir, apresentamos o esquema das etapas da SD que utilizamos na intervenção:

Figura 03 - Etapas da Sequência Didática desta intervenção

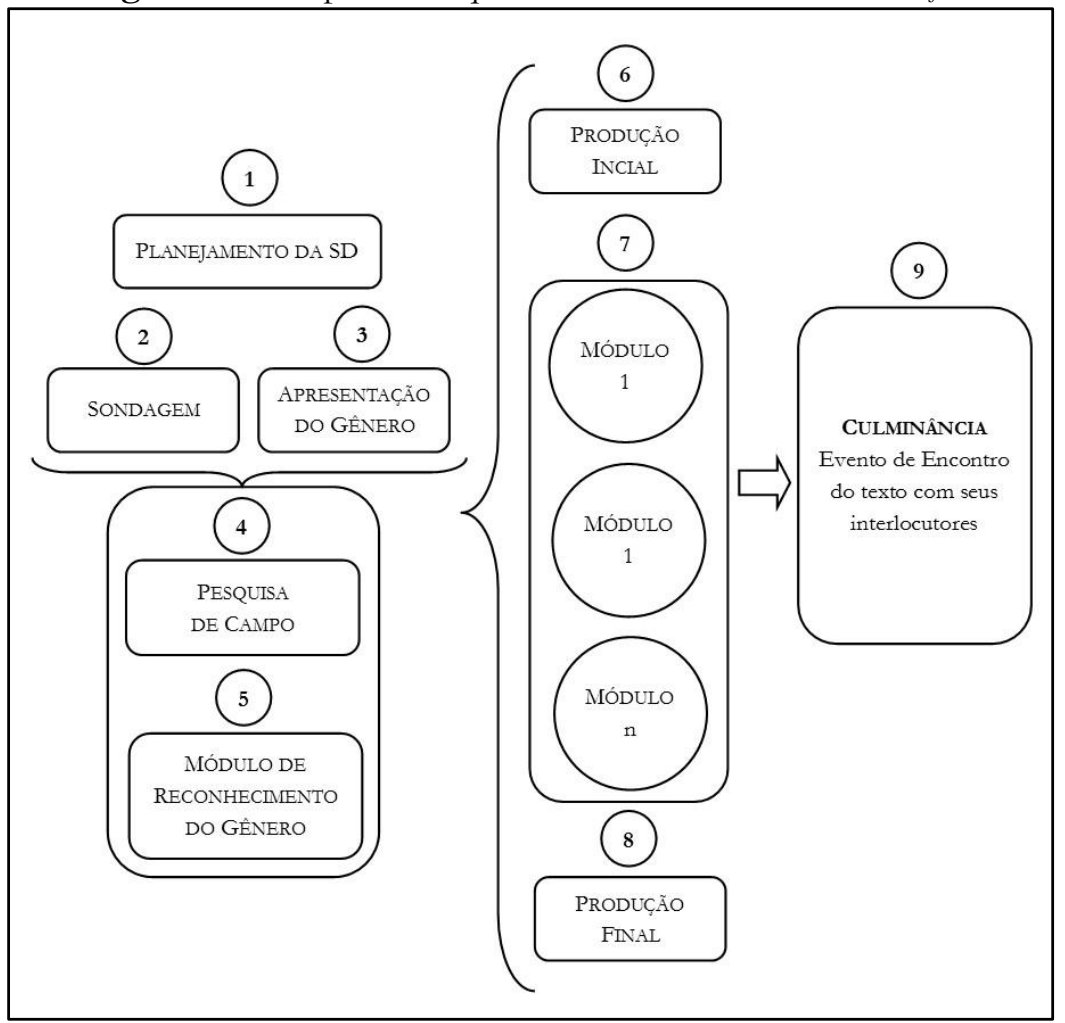

Fonte: Elaborado pelos autores.

Nessa pesquisa, o Planejamento da SD consistiu no primeiro momento da sequência didática. A partir da participação efetiva dos alunos, foi possível problematizar o trabalho com literatura em sala de aula, levando os alunos a refletirem sobre o "ser juazeirense" e de que forma a literatura pode representar um povo ou uma cultura. A partir daí, foram explorados, também, os conhecimentos prévios dos alunos acerca da temática e outros questionamentos afins, envolvendo os alunos na tomada de decisões. Em seguida, foram realizadas a Sondagem e a Apresentação do Gênero, seguida de uma Pesquisa de campo, da elaboração do Módulo de Reconhecimento do Gênero, da Produção Inicial, da elaboração e aplicação dos Módulos e 
Intervenção, a Produção Final e a Culminância. Segundo Brocardo e Costa-Hübes (2009, p. 12):

[...] antes da produção inicial de um texto do gênero selecionado, sentimos a necessidade de propiciar, aos alunos, situações de reconhecimento do gênero, oportunizadas por atividades de pesquisa, leitura e análise linguística de textos prontos, já publicados, que circulam socialmente (BROCARDO E COSTA-HÜBES, 2009, p. 12).

Os alunos foram motivados a pesquisar sobre o escritor escolhido e suas obras, desenvolvendo a autonomia no ato de localizar, observar, selecionar e sistematizar informações relevantes para a escrita da biografia. Planejamos uma conversa com a professora Odomaria Macedo, sobre o Acervo Maria Franca Pires, bem como uma visita ao acervo e uma conversa com escritores juazeirenses que se dispuseram a participar das atividades. Brocardo e Costa-Hübes (2009, p. 13) ressaltam que

[...] propiciar situações de pesquisa, leitura e análise linguística antes da produção inicial, significa subsidiar os alunos com conhecimentos necessários para que o processo da produção (oral ou escrita) aconteça.

Por isso, planejamos diversas atividades antes da Produção Inicial. A partir do primeiro texto produzido, percebemos as capacidades já adquiridas e ajustamos as atividades e os exercícios previstos na sequência didática às possibilidades $\mathrm{e}$ dificuldades reais da turma, seguindo as orientações de Dolz, Noverraz e Schneuwly (2004, p. 98).

Em seguida, foram aplicados os módulos ${ }^{1}$, que consistiram em materiais de apoio com atividades diversas com o objetivo de sanar as dificuldades percebidas na Produção Inicial. Nesses módulos foram abordados temas como os elementos da narrativa biográfica, reescrita da produção, multimodalidade, a plataforma do wordpress, entre outros. A Produção Final foi o produto do trabalho realizado com os módulos, no qual os alunos colocaram em prática os conhecimentos adquiridos. Nesse caso, a produção final consistiu na publicação da versão final do texto biográfico sobre um escritor local na biblioteca digital, com os hiperlinks, bem como a inserção de outros materiais produzidos no decorrer da aplicação dos módulos. Para apresentação do produto final, realizou-se o lançamento da biblioteca digital, num evento promovido pela turma.

\section{ALGUNS RESULTADOS DA INTERVENÇÃO}

Durante o desenvolvimento da intervenção, buscou-se realizar um trabalho em sala de aula com a leitura de textos literários de escritores locais, proporcionando aos alunos um contato prazeroso e também reflexivo com essa literatura. A partir

\footnotetext{
1 Os módulos foram elaborados exclusivamente para a intervenção e seguiram a metodologia utilizada no Laboratório de Recursos Didáticos da UEFS. A título de ilustração disponibilizamos em anexo, após as referências, uma das páginas do Módulo (Cf. Anexo A).
} 
disso, constatou-se que a literatura local pode e deve ser trabalhada no espaço escolar. No desenvolvimento das atividades, foram observados o empenho e envolvimento dos alunos com a temática abordada e o entusiasmo do grupo no momento de utilizar as ferramentas digitais.

Numa das atividades da Sondagem foi promovida uma discussão acerca da leitura na vida das pessoas. Os alunos puderam observar como o ato de ler está presente no nosso cotidiano e sua importância. Discutiu-se ainda acerca dos conceitos de texto literário, observando-se suas especificidades. Foi interessante observar que, muitas vezes, os alunos não consideram suas práticas de leitura fora da escola como leitura de fato, ou não atribuem o mesmo valor às práticas de leitura que realizam fora da sala de aula. As leituras realizadas informalmente, como nas redes sociais, por exemplo, não têm o mesmo valor para eles.

A segunda atividade da Sondagem iniciou-se com a discussão sobre o que é ser juazeirense e como a memória cultural de Juazeiro é representada. Muitos afirmaram não se considerarem juazeirenses ou não terem orgulho de serem juazeirenses, em virtude de não identificarem algo positivo para representá-los, pelo contrário, levantaram aspectos da cidade que despertavam uma certa rejeição pelo lugar onde residem. A partir daí, foi destacada a importância da literatura local e os próprios alunos chegaram à conclusão de que o texto literário poderia servir para denunciar o descaso das autoridades pela cidade, ou ainda para ressaltar o que existe de bom e belo. Isso foi constatado pelos alunos ao lerem alguns textos dos escritores juazeirenses. A leitura e discussão do poema Canção para João cantar fez com que os estudantes ativassem seus conhecimentos prévios, recordando do cantor e compositor juazeirense João Gilberto. Isso reforçou a discussão acerca da valorização do local. Nessa discussão, os alunos sinalizaram ainda o descaso do governo local com o patrimônio histórico da cidade, como monumentos ou espaços que poderiam ser pontos turísticos e que estão abandonados, como a antiga estação ferroviária, por exemplo, ressaltando a importância desse patrimônio para a história da comunidade.

$\mathrm{Na}$ atividade de Apresentação do Gênero, os alunos tiveram contato com o texto biográfico de um escritor local. Para essa atividade, disponibilizamos diversos livros de escritores de Juazeiro e foi possível discutir sobre os livros, juntamente com as informações adquiridas nas pesquisas solicitadas posteriormente. Após a leitura dos textos, houve um momento para se discutir e aprofundar as especificidades do texto biográfico, assim como sua importância para a preservação da memória local. Os alunos compararam as biografias de escritores com biografias de artistas e de políticos.

Antes da Produção Inicial, os alunos foram orientados acerca da sistematização das informações necessárias para a escrita da biografia e de mecanismos de pesquisa para coletar mais informações.

O primeiro módulo de intervenção trouxe outros textos da literatura local para a discussão, possibilitando a ampliação do conhecimento dos alunos acerca dos textos e proporcionando uma reflexão sobre o uso das imagens atrelada ao texto alfanumérico. A intenção foi preparar os alunos para a composição do texto multimodal e das diversas semioses que estão implicadas nos textos veiculados na web. 
$\mathrm{Na}$ sequência, os alunos receberam a visita do escritor João Gilberto para falar um pouco sobre sua história como leitor e da professora Odomaria Macedo, responsável pelo Acervo Maria Franca Pires, da Universidade do Estado da Bahia, para falar sobre sua história com o acervo. O contato com o escritor e compositor João Gilberto foi muito relevante porque os alunos puderam compreender o compromisso do escritor com a sua terra natal. $\mathrm{Na}$ visita da professora Odomaria, os alunos aproveitaram para questionar também sobre os escritores sobre os quais escreveram as biografias, visto que o acervo foi fonte para suas pesquisas. Em ambas as conversas, com o escritor e com a professora, os alunos questionaram sobre pessoas que influenciaram suas vidas e escolhas, quiseram saber se havia essa postura de influência em suas famílias, perguntaram a opinião sobre a situação do patrimônio juazeirense, entre outras questões.

Os estudantes também visitaram o Acervo Maria Franca Pires para conhecer melhor sobre a sua importância e apropriar-se de alguns posicionamentos acerca da valorização desse material. Durante a visita, os alunos demonstraram empolgação ao verem fotos antigas da cidade, bem como as cartas e materiais que constituem o acervo, como por exemplo, uniformes antigos, jornais, entre outros. Além das modificações nas paisagens locais, observaram também as diferentes formas de escrita que estiveram em vigor em outras épocas.

Figura 04: Visita dos estudantes ao Acervo Maria Franca Pires

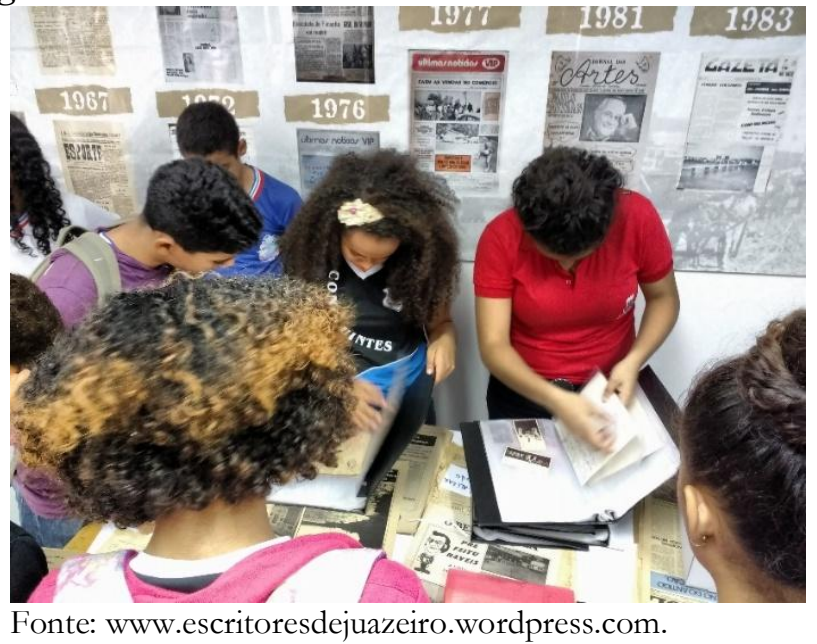

Posteriormente, foi apresentada uma avaliação global dos textos da Produção Inicial, apontando os pontos fracos e os pontos fortes, com orientações pontuais para corrigir e ampliar os textos. Assim os alunos aprofundaram a pesquisa sobre os escritores e foram progressivamente ampliando e corrigindo os textos. Em seguida, foi aplicado o módulo dois, que discutiu a questão da multimodalidade, hipertextos, wordpress, inserção de links, entre outros aspectos do meio digital. Esse módulo problematizou a questão da crescente revolução tecnológica, trouxe exemplos de textos multimodais e apresentou a plataforma wordpress com orientações sobre como inserir links, criar páginas e publicar textos no site. 
Foi interessante observar a empolgação dos alunos ao perceberem que eram capazes de manipular as ferramentas do wordpress. A partir daí, iniciou-se a etapa de realizar a produção final, transpondo os textos para o ambiente da plataforma do wordpress. Os alunos digitaram seus textos utilizando notebooks ou aparelhos celulares, inseriram as imagens e os links diretamente na plataforma de edição do wordpress, sob a mediação da professora.

A biblioteca digital está organizada a partir de uma página inicial com diversos posts com notícias acerca das atividades desenvolvidas durante a intervenção e uma barra de menu contendo as seguintes páginas: Sobre, Escritores Locais, O Acervo Maria Franca Pires, Escritores de Juazeiro na Escola, Juazeiro.

Figura 05 - Etapas da Sequência Didática desta intervenção
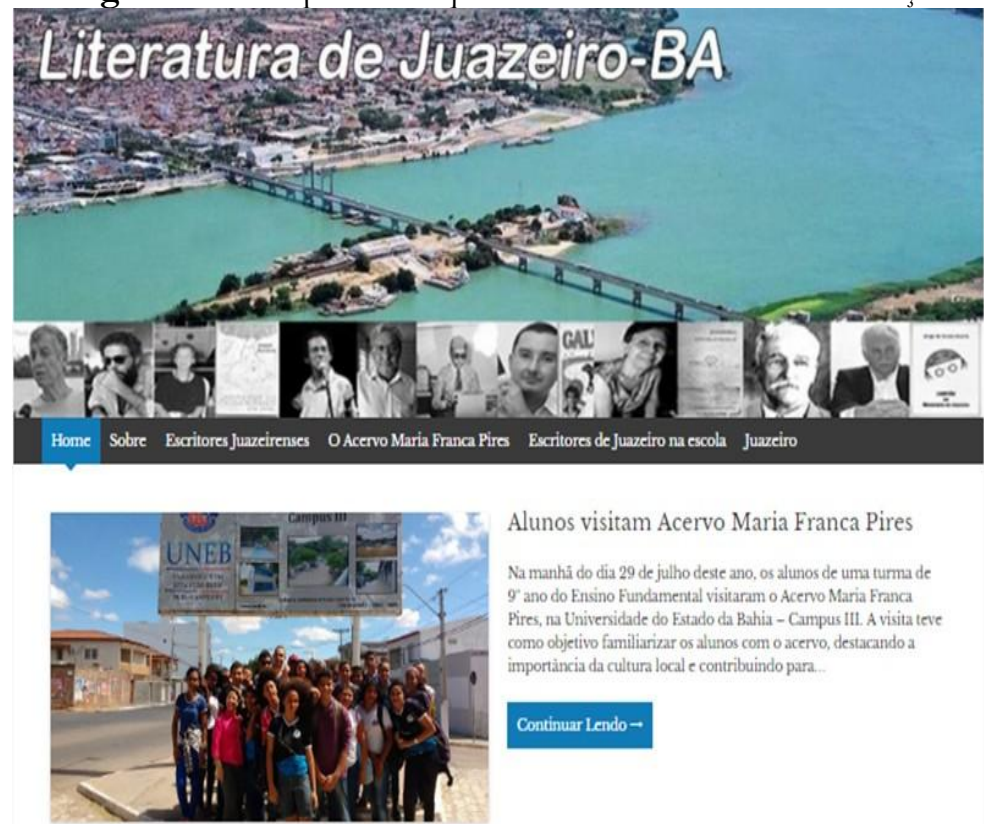

Alunos visitam Acervo Maria Franca Pires

Na manhả do dia 29 de jullho deste ano, os alunos de uma turma de 9 ano do Ensino Fundamental visitaram o Acervo Maria Franca Pires, na Universidade do Estado da Bahia - Campus III. A visita teve como objetivo familiarizar os alunos com o acervo, destacando a importancia da cultura local e contribuindo para.

\section{Continuar Lendo-}

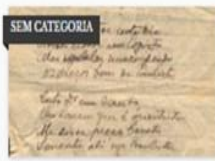

Literatura local e legislação

Sabe-se que a literatura local ainda nào possui o espaço que se almeja nas salas de aula de lingua Portuguesa, embora o Artigo 26 da Lei de Diretrizese

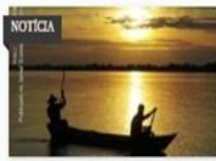

O Rio e as Pessoas são a nossa poesia

A cidade de Juazeiro-BA está integrada à paisagem, bebe a água doce do Rio Sio Francisco ese mistura às criaturas mitológicas que habitam

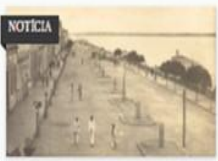

$\mathrm{O}$ acervo Maria

Franca Pires

Um variado acervo da cultura regional que foi guardado como objeto de memória pela professora Maria Franca Pires no decorrer de sua vida é objeto de

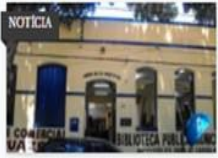

Os escritores de Juazeiro-BA nas Bibliotecas da Cidade

Tracando um parorama acerca da presenga de bibliotecas na cidade, nota-se que além de as escolas públicas nem sempre

Fonte: www.escritoresdejuazeiro.wordpress.com.

No menu Sobre, encontra-se um texto que contextualiza o projeto de intervenção. O menu Escritores de Juaz̧eiro disponibiliza uma lista com os nomes dos escritores que dá acesso à página que contém a biografia e textos literários dos escritores, em forma de contos, crônicas e poesia. 
Em linhas gerais, pode-se afirmar que as produções iniciais conseguiram contemplar as características básicas do gênero biografia, embora alguns textos não tenham sido satisfatórios por consistirem em cópias de textos de outras fontes. É possível constatar que os textos atendem aos requisitos do gênero biografia, mesmo com certo grau de informatividade inerente aos usos linguísticos dos estudantes.

Por exemplo, o texto A, referente ao escritor Agostinho José, foi escrito com uma linguagem informal, não apresentou paragrafação, trouxe falhas na ortografia e pontuação e poderia trazer mais informações acerca do escritor. A reescrita do texto na publicação na biblioteca digital buscou sanar esses problemas.

Nascido no dia 10 de fevereiro de 1901, na cidade de juazeiro-ba, teve uma infância com notas regulares, vindo com isso, alcançava os primeiros lugares. Ou seja, "ele era o cara". Sempre teve facilidade em história do Brasil e ciências, o cara manjava, mas, o seu saber não era suficiente, ele queria ingressar na Escola Estadual Da Bahia, capital de Salvador. Com muito esforço e dedicação, foi trabalhar em Salvador, tendo que deixar sua boa cidade "Juazeiro", seu esforço foi adiante, e entrou na faculdade de medicina. Não podendo concluir por conta de estudar pela manhã, e trabalhar a noite, teve a saúde afetada, dedicou-se ao novo campo "O magistério". Com muitas idas e vindas, tornou-se professor primário em Salvador, sentindo falta de sua terra natal, voltou para juazeiro, e fundou sua primeira Escola. Como hoje é conhecida por "Agostinho José de Muniz", no centro de Juazeiro-ba. (Produção Inicial, aluno A).

Figura 06 - Produção final, aluno A (Página de Agostinho José Muniz)

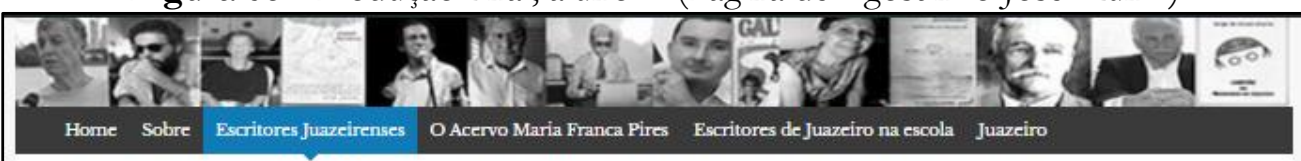

Agostinho José Muniz

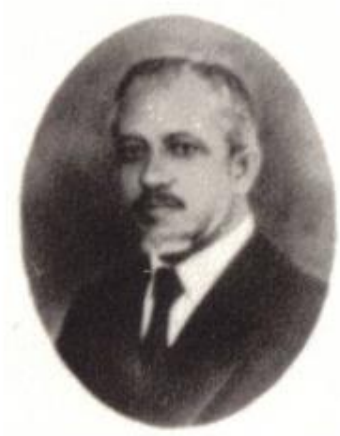

Nascido no dia 10 de fevereiro de 1901, na cidade de Juazeiro-BA, desde cedo teve um rendimento escolar notável.

Sempre teve facilidade em História do Brasil e Cièncias, mas achava que seu conhecimento nẫ era sulcie queria estudar na capital Salvador. Ainda em Juazeiro, começou a trabalhar e estudar. Mais tarde, permaneceu com as mesmas atividades em na capital.

Com muito esforço e dedicação, concluiu o ginásio e ingressou na faculdade de medicina Näo pode, no entanto, concluir por estudar pela manhã e trabalhar à noite, o que afetou a sua saúde. Ainda no primeiro ano de curso, abandonou o curso de medicina e dedicou-se a um novo campo: o magistério.

Começou a lecionar ainda em Salvador, mas tinha o desejo de voltar a Juazeiro para lá ser professor. Sentindo falta de sua terra natal, voltou para Juazeiro $e$ fundou a primeira

Fundou, também, o jornal $O$ Trabalho, fruto de seus estudos sobre as leis e relaçôes de trabalho. Foi um decepcionado politico, tendo fundado o Partido Uniāo Trabalhista Juazeirense e exercido o cargo de vereador entre 1951 e 1955.

Seu envolvimento na esfera política permitiu que Agostinho concretizasse os seus planos de instalar o Ginásio em Juazeiro. Fundou, entâo, em parceria com outros professores, politicos e parceiros de Juazeiro, o Colégio Ruy Barbosa. Foi o primeiro diretor do Colégio e, com muito esforço (pois, muitas vezes, saia pelo comércio e pelos Bancos da cidade pedindo dinheiro emprestado para pagar os professores, até que recebesse algum auxilio do govemo), conseguiu manter as portas abertas para a classe menos favorecida do município.

O politico, escritor, poeta, professor Agostinho José Muniz é, sem dúvidas, um dos maiores contribuintes da educação juazeirense. Agostinho Muniz adoeceu e faleceu em 10 de janeiro de 1960.

Alunos: Alítio, Antonio e Jackson

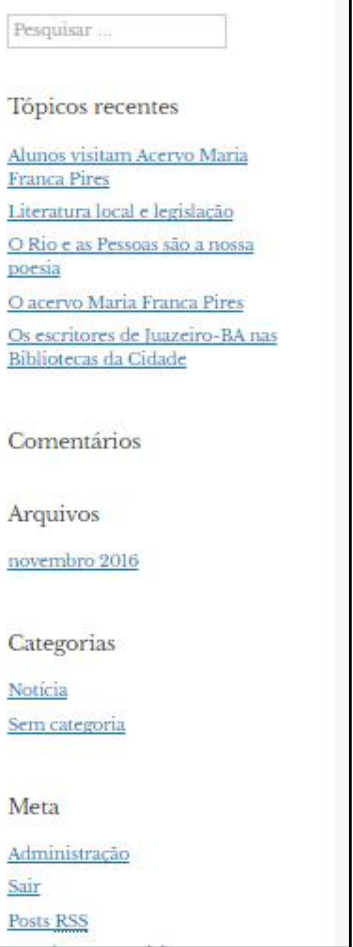

Fonte: www.escritoresdejuazeiro.wordpress.com. 
Figura 07 - Poesias de Agostinho José Muniz

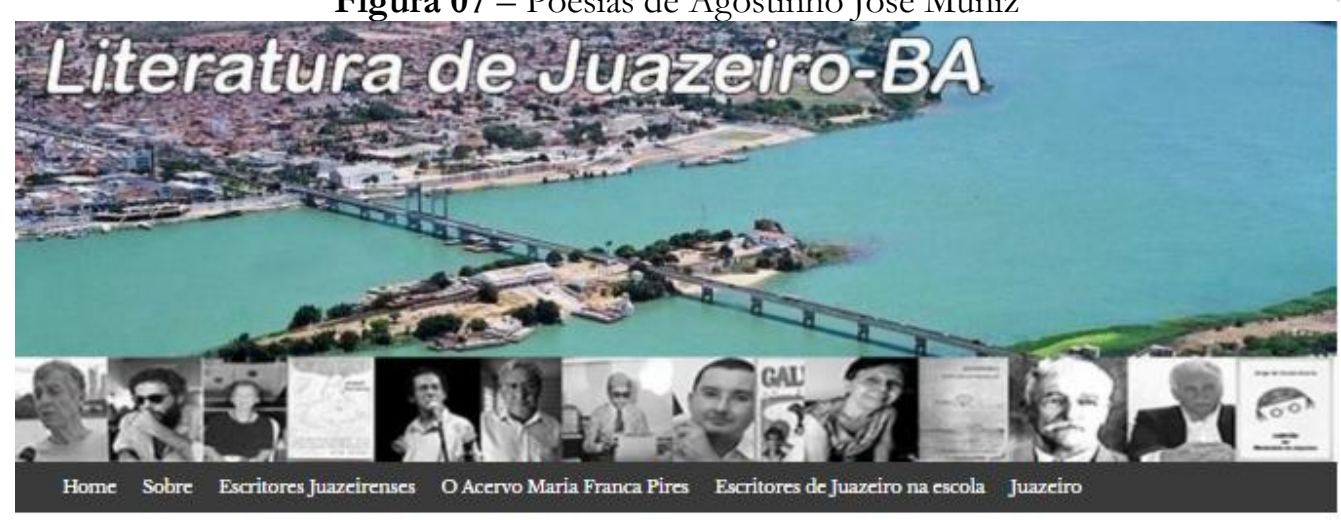

Poesia de Agostinho José Muniz

PROFISSÃO DE FÉ

Capitólio longínquo, onde quer que demores

Um dia hei de alcançar-ter, do meu ideal ao fim.

Que nảo me falta a fé, nem me falece ardores,

Não me conduza, embora, em áureo bergantim.

Nào por palmas, lauréis, púrpura, sólidos, sólios, flores,

Sagraçóes pessoais, ou pedestaes de marfim

Mais a vida da Idéia - a Obra cheia de esplendores,

Tal qual mente a sonhei $e$ a sinto dentro de mim

Hei-de vé-la surgir, alevantar-se e erecta,

Florescer, a dar frutos, influindo directa

Em mais altos ideaes da moça geração

Que não quero outra glória e nem sonho outro feito

E nem pode viver no estreito do meu peito

Mais elevado anseio, mais larga aspiração [sic].

Agostinho José Munis.

Poesia publicada no Jornal "O ECHO", datado de 16 de Maio de 1931.

Por Edilane Ferreira

Fonte: O arquizo de Maria Franca Pires: memoria e historia cultural na regiāo de Juazeiro-BA, disponivel no Blog: http://parlim_blogspot.com.br/2011/07/agostinho-jose-muniz-fragmentos-de-uma.html

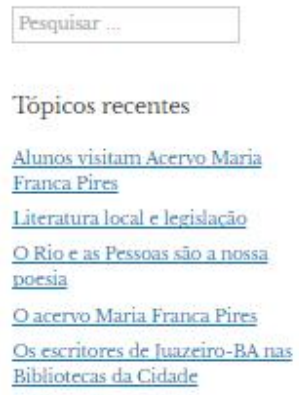

Comentários

Arquivos

novembro 2016

Categorias

Noticia

Sern categoria

Fonte: www.escritoresdejuazeiro.wordpress.com.

A produção final acerca de Agostinho Muniz acrescentou informações ao texto inicial, melhorando na seleção vocabular, nos recursos expressivos, semânticos, sintáticos, entre outros. Foram inseridos links, no intuito de fornecer informações extras ao texto. Além disso, após a biografia dos escritores, as páginas dos escritores oferecem a possibilidade de acessar outras páginas com textos, imagens, vídeos e sugestões de outros sites. 
Figura 08 - Produções Inicial e Final da Biografia de Euvaldo Macedo- aluno B

\section{TRANSCRIÇÃO DO TEXTO MANUSCRITO}

Euvaldo Macedo Filho nasceu em Juazeiro em 1952, fotografo, poeta. Seu pai era comerciante na cidade e sua mãe tinha uma escola de datilografia. Foi pra Salvador estudar economia já que seu pai queria um economista na família, porém Euvaldo desistiu no último ano e voltou pra Juazeiro, onde conheceu Odomaria Macedo. Fez um vestibular de administração em Petrolina, quando ele mais se dedicou a poesia, passava tardes escrevendo na máquina de datilografia. Publicou nas revistas de fotografia, pois tinham tanta qualidade que simplesmente ao chegar na editora eram aprovadas, como a revista foto câmera de 70 e 80 . Enviou de Juazeiro para o México para um concurso internacional de comemoração mundial do dia das crianças em 1979, um conjunto de fotografias de crianças no rio e foi classificado sem ir ao México enviando as fotos pelo correio. Foi para São Paulo mas não se deu muito bem por causa da poluição, era alérgico a isso é tinha um tipo de asma, ficou lá por dois meses e pegou uma gripe e voltou para Juazeiro. Precisou fazer uma cirurgia de vesícula e teve um choque anafilático, morrendo com 30 anos de vida, deixando um monte de coisas escritas e fotografias, nos quais Odomaria Macedo, sua esposa, está cuidando de publicalos.

\section{TEXTO INSERIDO NO SITE}

Euvaldo Macedo

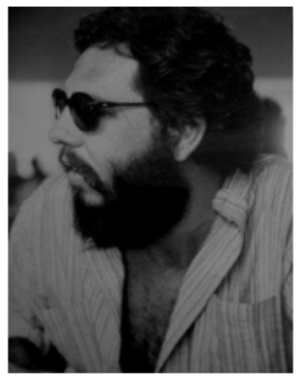

Euvaldo Macedo Filho nasceu em Juazeiro, em 1952. Foi fotógrafo e poeta.

Filho de pai comerciante sua mãe professora de datilografia, foi para Salvador, ainda jovem, estudar Economia, já que seu pai queria um economista na familia. Euvaldo, porém, desistiu no último ano do curso e voltou pra Juazeiro, onde, mais tarde, conheceu Odomaria Macedo. Fez um vestibular para o curso de administração, em Petrolina, e iniciou a graduação. Foi nesse período que mais se dedicou à poesia: passava tardes escrevendo na máquina de datilografia.

Publicou em diversas revistas de fotografia, como a revista Foto Câmera em 1970 e 1980, suas fotos tinham grande qualidade: eram quase sempre publicadas tão logo chegassem às editoras. Em 1979, enviou para um concurso internacional em comemoração ao dia das crianças, no México, um conjunto de fotografias de crianças no rio São Francisco e, mesmo sem estar presente no local do concurso, foi classificado, enviando as fotos pelos Correios.

Passou um período em São Paulo, mas não se deu muito bem por causa da poluição, porque era alérgico a isso e tinha um tipo de asma. Ficou lá por dois meses: pegou uma gripe e voltou para Juazeiro.

Em 1982, precisou fazer uma cirurgia de vesícula e teve um choque anafilático, morrendo com 30 anos de vida, deixando um variado acervo de textos escritos e fotografias, os quais Odomaria Macedo, sua esposa, está organizando para publicar.

Alunos: Gessé Barros e Israel Lucas

Por Ele Mesmo

"Eu nunca recebi de graça porra nenhuma em minha vida, nem nunca contei com receber nada de graça. It's a long away. Tudo que eu tive e já consegui foi a custa de muito esforço. Uma quase penitência. Eu investi em mim. Trabalhei em mim.

Eu sou diferente da maioria das pessoas. Mas não gosto muito de fazer esse papel.

Sou sonhador, é verdade. Gentil?

Já dei golpes que machucaram, e também os recebi, no campo afetivo. Sou vulnerável e ultra sensível. Tento me poupar e aos outros, mais vivemos como loucos. Gostaria que existisse um mundo suave, onde as pessoas apenas trocassem carícias."

"É tão bonito acompanhar o voo de uma pessoa no sentido da realização de seu sonho."

Fonte: Baú de Euvaldo, Rascunhos Manuscritos.
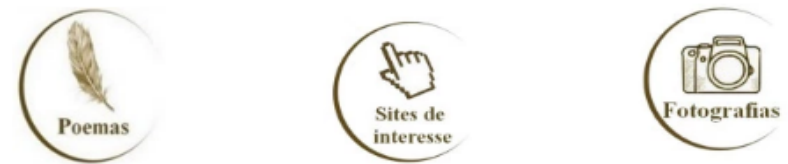

Fonte: www.escritoresdejuazeiro.wordpress.com.

Um dos textos mais completos é o que se refere à escritora Layse de Luna Brito. Apresenta bastante informações acerca da autora, em diversas - e relevantes - fases de sua vida. Há, no entanto, considerável dificuldade quanto à coesão do texto, principalmente no seu início, indício de que a pesquisa carecia de aprofundamento e do aproveitamento de textos de outros autores sobre a escritora. 


\section{$\mathrm{Na}$ revisão, foram adicionadas informações de outras fontes, corrigidos os erros na escrita e excluídas informações pouco relevantes, ao menos para o objetivo do trabalho.}

\section{Figura 10 - Produções Inicial e Final da Biografia de Layse de Luna Brito - Aluno D}

Nascido no dia 5 de janeiro de 1891, na cidade de juazeiro BA. Seu pai Antônio Luiz de Queiroz , foi um grande político de juazeiro, possuía um grande conceito social e vivia muito bem economicamente . Devido à esse motivo, Raul tinha tudo em suas mãos : mocidade, conceito, dinheiro e inteligência. Somente aos 18 anos Raul dava o primeiro passa na sua vida poética, tendo publicado o soneto 'Meu Amor', dedicado às Magnólias, no jornal Correio do São Francisco. Como a vida sempre reserva surpresas para nós, para o poeta não foi diferente. Com dinheiro e inteligência , não demorou muito para o jovem poeta se tornar amante e bom amigo da bebida. Nesse mesmo período, em que a vida boemica começava a se destacar em Raul, ele se apaixonou loucamente pela jovem Olímpia de Souza, e casou-se com ela (contra a vontade de ambos os pais). A parti daí, a vida de Raul desabou e desde então foi marcada por traições , tristezas e pelo o alcoolismo. E com Olímpia teve dois filhos que morreram, e a história desse casamento resultou em três sonetos que resumem sua vida amorosa : Noivado, Casamento e Adultério. Depois desses trágicos acontecimentos , tudo começou a piorar, mas ainda sem família, sem dinheiro, Raul começou a andar de bar em bar, em busca do alivio na bebida. Assim foi a vida errante e poética de Raul. Viveu dessa forma até o dia em que sua esposa morreu . Com a morte de Olímpia , a sua vida melhorou, moderou na bebida e deu uma nova chance para se mesmo ; contraiu um verdadeiro amor com a jovem Raimunda Lopes, com quem viveu feliz até o último dia de sua vida. Raimunda foi uma esposa leal, amiga e sincera. Nesse segundo matrimonio teve dois filhos : Benedito e Benedita .

E foi esta a melhor fase de sua vida e também de maior produção literária . O soneto 'O Gênio ', considerado por muitos , a sua melhor produção (Transcrição do texto)

Layse de Luna Brito

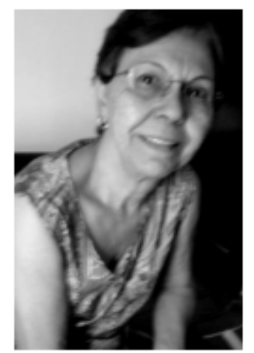

Layze de Luna Brito é juazeirense, mas foi criada em Petrolina/PE. Passou sua infáncia e adolescência lá, onde foi viveu com uma tia, irmã de seu pai, mas por volta de 1970 voltou para Juazeiro. Desde do jardim de infância, estudou no colégio Nossa Senhora Auxiliadora, em Petrolina. Ainda criança, decidiu morar com a tia Leticia de Oliveira Brito.

Decidiu? Uma pequena criança e já com o poder de decisaio?

Esse era o prenúncio de que, no futuro, seria uma mulher determinada, sem medo nem "Papas na Língua", como reconheceria a comunidade juazeirense, anos mais tarde.

Já na infầncia, o gosto pela leitura e escrita a destacava entre os colegas. Foi autora de peças teatrais para escola Colégio Auxiliadora, onde foi incentivada por freiras que a ajudavam e davam grande incentivo para aumentar o gosto pelas letras, que desde cedo mostrava ser algo sério. Ainda na escola, escreveu peça uma completa (cujo o nome ficou no tempo) e adaptaçôes. Para uma de suas peças, convidou o entâo bispo da diocesano, Dom Avelar. Era uma comédia. Layze lembra de suas risadas enquanto assistia, sinal de que gostou.

A própria escritora se perguntara, por diversas vezes: seria esse talento uma herança ou gosto por ela adquirido sem influẻncias? Ainda criança se destacava por isso e já na adolescència participou de concursos literários, conquistando, com frequência, o primeiro lugar. Se a resposta fosse herança, essa íntima relação com as letras pode ter vindo de seu tio Elce de Oliveira Brito, também amante das poesias. Decerto, foi ele que colocou o gosto pelas letras na sua cabeça: quando ela queria saber o significava de uma palavra, ele vinha com dicionário e dizia: procure! Nunca dava pronto. Também sua bisavó fazia versos; mesmo sendo semianalfabeta, quando alguém dizia: Dona Felismina Brito, faça uns versos sobre assunto tal - ela prontamente os fazia.

Não passou pela formação Acadēmica de Letras. Cursou pedagogia em Salvador porque, na época, Juazeiro não possuía escola de nível superior. Fez licenciatura curta pelo estado para ser Orientadora Pedagógica, correspondente ao nível superior. Por isso começou a trabalhar no Núcleo de Supervisão Pedagógica, atual sede da diretoria Regional de Educação (Direc15). Fez, ainda em Salvador, um curso intensivo ofertado pelo Instituto Nacional de Estudos Pedagógicos (INEP). Ocupou o cargo de orientadora pedagógica por quase 5 anos. Trabalhou, ainda, na COE.L.BA, em Salvador (entre 1980 e 1989) e em Juazeiro (de 1989 até a aposentadoria).

Em Salvador, produziu - praticamente só - um jornal de circulaçâo interna naquela unidade da COE.LBA, atividade não realizada na volta a Juazeiro por falta de espaço na nova unidade. Aposentou-se pós 25 anos de serviços prestados ao Estado da Bahia e um pouco menos à COEL.BA, mas trabalhou como assessora de uma vereadora de Juazeiro, na década de 1990.

Naturalmente, a participação que tem Layze na história da imprensa local decorre de sua presença e efetiva atuação na política e da intimidade com a arte de escrever e a desenvoltura na produção literária. O Hino oficial de Juazeiro (letra), por exemplo, é uma de suas composiçōes notáveis.

"Um dia alguém me chamou de juazeirense de última hora. É porque essa pessoa pensa que amar é fazer alarido em tomo do objeto de nosso zelo."

De um espírito inquieto, por assim dizer, nasceram as crónicas ainda mais inquietantes de Layze de Luna Brito. Dois anos antes de ir morar em Salvador, já acostumada com a escrita, $e$ agora perto dos 20 anos, a jovem Layze - já professora no colégio onde estudou - recebe um convite de Marta Luz Benevides, uma das mulheres mais representativas da cidade de juazeiro naquela época. Marta Luz é escritora, cronista. radialista, autora de importantes programas radiofónicos. Por suas mãos surgiram programas como Pagão, Programa Educativo, e o também famoso E nós para onde vamos?, apresentação de crónicas surgido em 1971 cujo nome fora dado por Marta, aproveitando o final da primeira crónica apresentada no programa, de autoria de Layze de Luna Brito.

Pela conståncia com que escrevia, ao término do primeiro ano os temas foram ficando escassos e pediu a Marta que arranjasse mais uma pessoa para lhe ajudar. Fui assim que Joaquim Muniz Barreto iniciou uma parceria com Layze, alternando os dois de escrito. Depois disso, apareceram outros cronistas ouvintes como as professoras Antonila Cardoso e Esmelinda Pergentino, o professor e politico Joseph Bandeira que completaram a equipe de Marta ficando um a cada dia da semana.

Além desse sucesso vivido no rádio, Layze também imprimiu sua marca no periódico Rivale. Neste jornal, em 1973 era editora chefe, fazia editorial, corrigiu as matérias e, de vez em quando, escreveu outros textos como poesias. O proprietário Jorge Khoury, na época estudante de

Fonte: www.escritoresdejuazeiro.wordpress.com. 
O texto inicial sobre Raul da Rocha de Queiroz apresenta muitas falhas no uso da pontuação, algumas falhas na ortografia, limitando-se ao que diz respeito à vida literária do escritor, o que pode ser justificado pela escassez de fontes acerca do autor. No texto final, essas falhas foram corrigidas, exceto pela informatividade, que não possuía outras fontes além da utilizada para possíveis acréscimos. O texto biográfico sobre Raul da Rocha de Queiroz contou com um poema narrando a vida do escritor, produzido pela aluna, que participou da produção de sua biografia, conforme pode ser visto em: https://escritoresdejuazeiro.wordpress.com/raul-darocha-de-queiroz/.

A biblioteca digital Literatura de Juazeiro- $B A$ pode ser acessada pelo endereço eletrônico: www.escritoresdejuazeiro.wordpress.com e pretende-se que continue a ser alimentada e aprimorada. A expectativa é que o site seja acessado por quem se interesse pelos escritores de Juazeiro, especialmente professores e estudantes.

Diante dos objetivos traçados pela pesquisa, foi possível formular estratégias teórico-metodológicas que inserissem a literatura local no ensino de Língua Portuguesa. Foi possível que os alunos percebessem a importância de se trabalhar com essa literatura, em vista da valorização de sua identidade cultural. Foram inventariados alguns escritores de Juazeiro-BA e o material pesquisado foi disponibilizado pelos alunos na biblioteca digital. Os alunos agiram como protagonistas, pesquisando, produzindo textos, editando a página e os textos na plataforma do wordpress, publicando seus próprios textos. A função do professor, nesse sentido, transcendeu a de transmissor de conhecimentos, e abarca, de fato, o papel de mediador de saberes.

Por fim, os caminhos teórico-metodológicos adotados para a elaboração do projeto de intervenção foram suficientes para suprir as expectativas formuladas inicialmente, no que diz respeito à aprendizagem dos estudantes.

\section{REFERÊNCIAS}

BRASIL. Secretaria Nacional da Educação Fundamental. Parâmetros Curriculares Nacionais: língua portuguesa, terceiro e quarto ciclos. Brasília: MEC, 1998.

BROCARDO, R. O. COSTA-HÜBES, T. C. A elaboração do modelo didático de gênero e da sequência didática: uma perspectiva de trabalho com o gênero textual reportagem impressa em sala de aula. Disponível em: https://profletrasuefs.files.wordpress.com/2015/03/2004-8.pdf Acesso em: $14 / 09 / 2015$.

CARINO, J. A biografia e sua instrumentalidade educativa. Educ. Soc. [online]. 1999, vol.20, n.67, pp. 153-182. Disponível em: http://www.scielo.br/pdf/es/v20n67/v20n67a05.pdf Acesso em 06/11/2015.

COSSON, R. Letramento literário: teoria e prática. 2. ed. São Paulo: Contexto, 2014. 
DOLZ, J. NOVERRAZ, M. SCHNEUWLY, B. Sequências didáticas para o oral e a escrita: apresentação de um procedimento. In: SCHNEUWLY, B. DOLZ, J. E colaboradores. Tradução e organização: Roxane Rojo e Glaís Sales Cordeiro. Gêneros orais e escritos na escola. Campinas, SP: Mercado das Letras, 2004.

DELL'ISOLA, R.L.P. Retextualização de gêneros escritos. Rio de Janeiro: Lucerna, 2007.

FERNANDES, C. S. Literatura e identidade: a recepção do texto literário na Penitenciária Estadual de Maringá. 2009. 115 f. Dissertação (Mestrado em Letras) Departamento de Letras, Universidade Estadual de Maringá, Maringá - PR, 2009.

MACHADO, A. R. CRISTÓVÃO, V. L. L. A construção dos modelos didáticos de gêneros: aportes e questionamentos para o ensino de gêneros. Linguagem em (Dis)curso - LemD, Tubarão, v. 6, n. 3, p. 547-573, set./ dez. 2006.

MARCUSCHI, L. A. Gêneros textuais: definição e funcionalidade. In: DIONÍSIO, A. et al. Gêneros textuais e ensino. Rio de Janeiro: Lucerna, 2002.

ROCA, G. D. Biblioteca escolar hoje: recurso estratégico para a escola. Tradução: Carlos Henrique Lucas Lima. Porto Alegre: Penso, 2012.

ROJO, R. BARBOSA, J. P. Hipermodernidade, multiletramentos e gêneros discursivos. 1. ed. São Paulo: Parábola Editorial, 2015.

Freire, José Alonso Tôrres. Os saberes da literatura e a formação do leitor. Revista EntreLetras, n. 1, 2010.

BAKHTIN, M. Estética da criação verbal. Trad. Maria Ermantina Galvão Gomes e Pereira. São Paulo: Martins Fontes, 1992. 


\section{A leitura e o texto literário}

\section{O que vou aprender?}

- Duerendar textoc itserartos e nSo-iterdrioa.

\section{Video}

1. Assista ao video Manifesto a leitura e comente acerca da presença da leltura no cotidlano e sua Importancla.

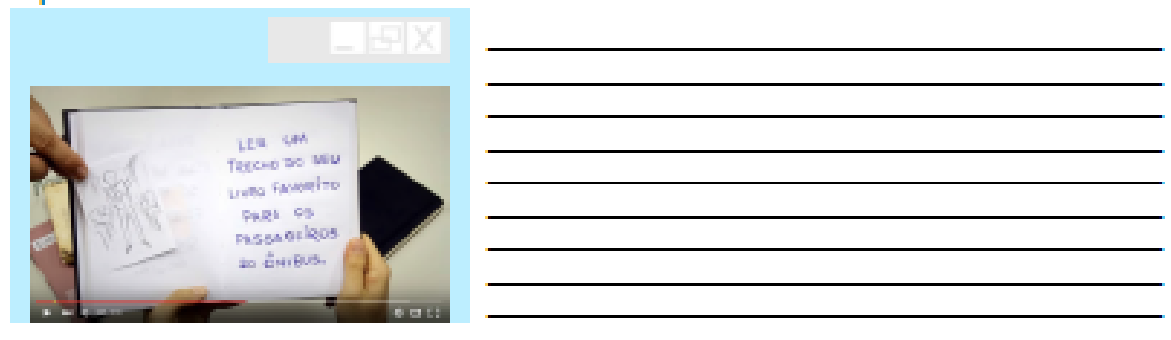

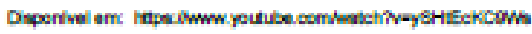

Interapäo entre leituras

Lela os textos que voce recebera, troque-os com seus colegas e discuta com eles sobre o que entenderam a partir das lehuras e o que elas tem em comum.

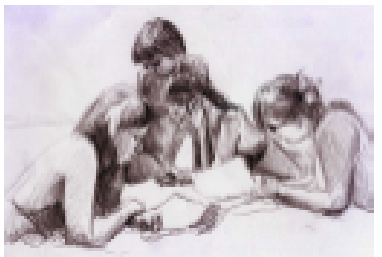

Ampliando seus conhecimentos

TEXTO 1

A PALAVRA E DE PRATA E O SILENCIO EE DE OUTRO

O slencio e uma calxa

Imensa onde cabem

e ressoam

todas as palavras

e ha que pescatlas com cuidado

stem as redondas

e madis,

palavras vaga-lumes,

que lluminam a boca

de amor e docura.

e outras com espinnos,

eoutras com espinhos.

no tundo da caxa do mundo.

Dentro do sllenclo

as palavras luminadas nadam

como pelixes dourados.

MUREAY, Rogesns. In: Quem us cara nfo ws coracto.

Ed. Calla \& Inestuto Houssa, 2012.
TEXTO 2

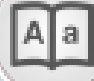

silencio

1. Ausencla de som ou ruldo: sllencio absoluto 2. Acto de náso falar. ficar em slencio; slencio:

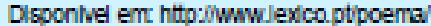
Acesso em 2B/02/2016. 